\title{
TU/e EmonOWEN

\section{Analysis of divalent metal dialkyldithiocarbamates by gas chromatography and mass spectrometry}

\section{Citation for published version (APA):}

Krupcik, J., Leclercq, P. A., Garaj, J., \& Masaryk, J. (1979). Analysis of divalent metal dialkyldithiocarbamates by gas chromatography and mass spectrometry. Journal of Chromatography, 171(1), 285-304.

https://doi.org/10.1016/S0021-9673(01)95308-7

DOI:

10.1016/S0021-9673(01)95308-7

Document status and date:

Published: 01/01/1979

\section{Document Version:}

Publisher's PDF, also known as Version of Record (includes final page, issue and volume numbers)

\section{Please check the document version of this publication:}

- A submitted manuscript is the version of the article upon submission and before peer-review. There can be important differences between the submitted version and the official published version of record. People interested in the research are advised to contact the author for the final version of the publication, or visit the $\mathrm{DOI}$ to the publisher's website.

- The final author version and the galley proof are versions of the publication after peer review.

- The final published version features the final layout of the paper including the volume, issue and page numbers.

Link to publication

\section{General rights}

Copyright and moral rights for the publications made accessible in the public portal are retained by the authors and/or other copyright owners and it is a condition of accessing publications that users recognise and abide by the legal requirements associated with these rights.

- Users may download and print one copy of any publication from the public portal for the purpose of private study or research.

- You may not further distribute the material or use it for any profit-making activity or commercial gain

- You may freely distribute the URL identifying the publication in the public portal.

If the publication is distributed under the terms of Article 25fa of the Dutch Copyright Act, indicated by the "Taverne" license above, please follow below link for the End User Agreement:

www.tue.nl/taverne

Take down policy

If you believe that this document breaches copyright please contact us at:

openaccess@tue.nl

providing details and we will investigate your claim. 
Journal of Chromatography, 171 (1979) 285-304

(1) Elsevier Scientific Publishing Company. Amsterdam - Printed in The Netherlands

CHROM. 11,553

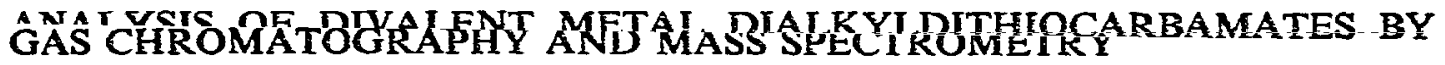

Department of Analytical Chemistry, Faculty of Chemical Technology, Slovak Techncal unuersiry, 88037 Brarislava (Czechoslovakia)

P. A. LECLERCQ

Laboratory of Instrumental Analysis, Eindhoven University of Technology, Eindhoven (The Netherlands) and

J. GARAJ and J. MASARYK

Department of Analytical Chemistry, Faculty of Chemical Technology, Slovak Technical University, 88037 Bratislava (Czechoslovakia)

(First received May 11 th, 1978; revised manuscript received October 19th, 1978)

\section{SUMMARY}

The influence of various gas chromatographic supports, coated with SE-30 as stationary phase, on the qualitative and quantitative analysis of $\mathrm{Ni}(\mathrm{II})$ and $\mathrm{Zn}(\mathrm{II})$ dithiocarbamates was investigated. Retention indices were correlated with the structures of the compounds studied. $\mathrm{Cu}$ (II), $\mathrm{Co}$ (II) and $\mathrm{Cd}$ (II) dialkyldithiocarbamates decomposed during analysis under the applied conditions. Special emphasis was given to the quantitative analysis of $\mathrm{Ni}(\mathrm{II})$ and $\mathrm{Zn}$ (II) bis(N,N-dialkyldithiocarbamates).

Basic conditions were established for the separation of $\mathrm{Ni}(\mathrm{T})$ bis(N,N-dialkyldithiocarbamates) on glass capillary columns.coated with polydimethylsiloxane stationary phases (OV-101 and SE-30). The main problem in the successful analysis of these compounds in glass capillary columns was found to be adsorption on the column wall.

Electron-impact positive-ion mass spectra of $\mathrm{Ni}(\mathrm{II})$ and $\mathrm{Zn}$ (II) bis(N,N-dialkyldithiocarbamates) are discussed in detail. From the mass spectra of these compounds, general fragmentation pathways were derived. All of the dithiocarbamates studied showed molecular ions, the intensity of which decreased with increasing size of the alkyl substituent.

\section{INTRODUCTION}

Successful analyses of metal chelates containing a dialkyldithiocarbamate ligand by gas chromatography have been recently published ${ }^{1-6}$. We have previously described the separation of nickel and zinc bis(N,N-diethyldithiocarbamates) ${ }^{2} . \mathrm{Zn}(\mathrm{II})$, $\mathrm{Cd}(\mathrm{II}), \mathrm{Pb}(\mathrm{II}), \mathrm{Hg}(\mathrm{II}), \mathrm{Ni}(\mathrm{II}), \mathrm{Pd}(\mathrm{II})$ and $\mathrm{Pt}(\mathrm{II})$ bis(N,N-diethyldithiocarbamates) have 
been analysed by gas chromatography ${ }^{3,4}$. The separation of a mixture of $\mathrm{Ni}(\mathrm{II})$, $\mathrm{Zn(II)}$ and $\mathrm{Cd}(\mathrm{II})$ bis(N,N-diethyldithiocarbamates) was also described by Tavlaridis and $\mathrm{NNeeb}^{5}$. For the determination of metals in water, Tavlaridis and Neeb proposed the gas chromatographic analysis of chelates containing a di(trifluoroethyl)dithiocarbamate ligand ${ }^{6}$. Fluorinated diethyldithiocarbamates are more volatile and show better thermal stability above $473^{\circ} \mathrm{K}$ than do the corresponding diethyldithiocarbamates. A mixture of $\mathrm{Zn}, \mathrm{Ni}, \mathrm{Cd}, \mathrm{Sb}$ and $\mathrm{Bi}$ bis $[\mathrm{N}, \mathrm{N}$-di(trifluoroethyl)dithiocarbamates] has been successfully analysed by gas chromatography.

For the analysis of metal dithiocarbamates hy gas chromatography, columns packed with non-polar stationary phases (silicone greases and elastomers) on silanized support materials based on Chromosorbs have been used exclusively ${ }^{1-6}$.

The mass spectra of metal $\mathbf{N}, \mathbf{N}$-dialkyldithiocarbamates have not yet been studied systematically ${ }^{2,7-16}$, and only a few mass spectral data have been reported on some dithiocarbamates of the bivalent metals $\mathrm{Cu}^{7}, \mathrm{Zn}^{7,12,13}$ and $\mathrm{Ni}^{2}{ }^{14}$. Detailed fragmentation patterns are not found in the literature.

The aim of the present work was to study the problems encountered in analyses of divalent metal dialkyldithiocarbamates by gas chromatography. Special emphasis is given to the quantitative analysis of $\mathrm{Ni}(\mathrm{II})$ and $\mathrm{Zn}$ (In) bis(N,N-dialkyldithiocarbamates).

Another objective of the work was to explore the basic conditions for the separation of $\mathrm{Ni}(\mathrm{II})$ bis(N,N-dialkyldithiocarbamates) by capillary column gas chromatography. Finally, the mass spectra of $\mathrm{Ni}$ (II) and $\mathrm{Zn}$ (In) bis(N,N-dialkyldithiocarbamates) are discussed in detail.

\section{EXPERIMENTAL}

\section{Preparation of divalent metal dialkyldithiocarbamates}

Dialkyldithiocarbamate chelates of divalent metals were prepared using the procedure described previously ${ }^{2}$. The chelates used are listed in Table 1 . The purity of the compounds obtained was checked by elemental analysis and mass spectrometry.

\section{Gas chromatography}

A Carlo Erba (Milan, Italy) gas chromatograph (Fractovap Model 2300) equipped with a flame-ionization detector (FID) and a stream splitter, allowing the use of capillary columns, was used.

Glass packed columns of length 60-200 $\mathrm{cm}$ and I.D. $3 \mathrm{~mm}$ were used. The support materials applied are listed in Table II. Glass capillary columns coated with OV-101 and SE-30 as stationary phases were prepared according to a previously described procedure ${ }^{17}$. The glass capillary columns used are listed in Table III. Capillary columns were coated using the dynamic plunger method ${ }^{17}$ and the modified static method $^{19}$.

Nitrogen was used as the carrier gas in all experiments. Samples of dithiocarbamates were dissolved in chloroform (1 mg in $1 \mathrm{ml}$ ). $n$-Alkanes were dissolved in $n$-hexane $(1 \mathrm{mg}$ in $1 \mathrm{ml})$. Solutions were injected with a $10-\mu l$ Hamilton microsyringe.

Peak asymmetry was measured at one tenth of the peak height ${ }^{20}$. Retention times were measured with a stop-watch. A digital integrator (Autolab, Model 6300) was used to measure peak areas for quantitation. 
TABLE I

DIVALENT METAL BIS(N,N-DIALKYEDETHIOCARBAMATES) STUDIED.

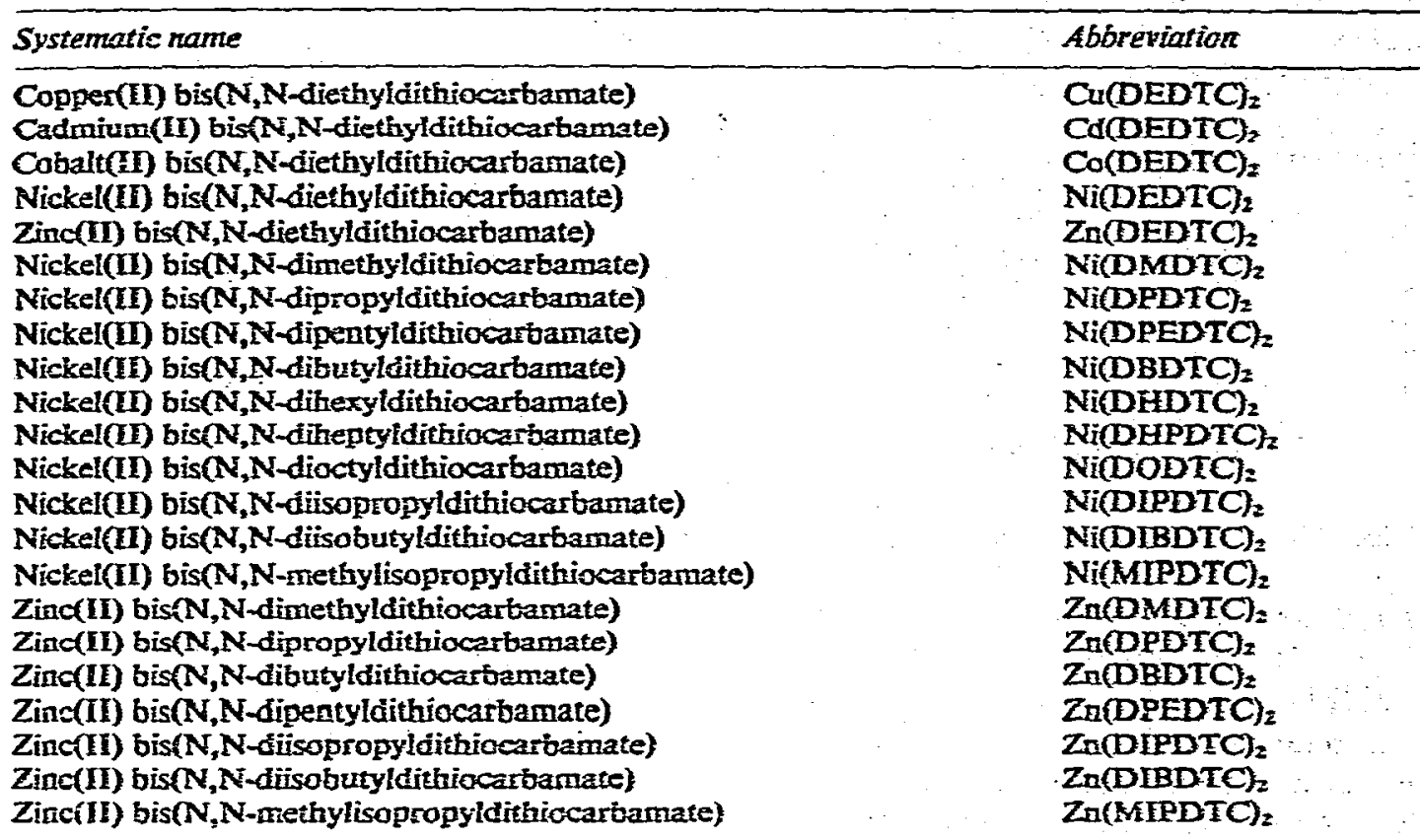

TABLE II

SUPPORTS USED

\begin{tabular}{lrl}
\hline Support & Mest range & Source. \\
\hline Gas-Chrom P sil.* & $100-120$ & Carlo Erba (Mfilan, Italy) \\
Chromosorb W sil. & $80-100$ & Carlo Erba \\
Chromosorb P sil. & $80-100$ & Carlo Erba \\
Chromaton N AW HMDS & $80-100$ & Lachema (Brno, Czechoslovakia) \\
Chezasorb AW EMDS & $60-80$ & Lachemia \\
Chromosorb G AW DMOS & $80-100$ & Packard-Becker (Delft, The Netherlards) \\
Chromosorb W & $80-100$ & Carlo Erba \\
Gas-Chrom Q & $100-120$ & Carlo Erba \\
\hline
\end{tabular}

- Silenization procedure is noe krown.

\section{Mass spectrometry}

Electron-impact positive-ion mass spectra were obtained on an AEI (Manchester, Great Britain) MS-12 single focussing mass spectrometer under the following conditions: electron energy, $70 \mathrm{eV}$; trap current, $0.500 \mathrm{~mA}$; ion accelerating yoltage, $4 \mathrm{kV}$; and source temperature, $520^{\circ} \mathrm{K}$. The compounds were admitted via a solid insertion probe. Spectra were obtained at probe temperatures within the ranges 420 $470^{\circ} \mathrm{K}$ for the nickel chelates and $390-450^{\circ} \mathrm{K}$ for the zinc chelates. 
TABLE III

GLASS CAPILLARY COLUMNS

\begin{tabular}{|c|c|c|c|c|c|}
\hline \multirow{2}{*}{$\begin{array}{l}\text { Column } \\
\text { No. }\end{array}$} & \multirow{2}{*}{$\begin{array}{l}\text { Length } \\
(m)\end{array}$} & \multirow[t]{2}{*}{ Stationary phase } & \multirow{2}{*}{$\begin{array}{l}\text { Coating } \\
\text { procedure }\end{array}$} & \multicolumn{2}{|l|}{ Etching } \\
\hline & & & & Time $(h)$ & Temperature $\left({ }^{\circ} \mathrm{K}\right)$ \\
\hline$\overline{1}$ & $31: 4$ & $10 \%$ OV -101 & Dynamic & 2 & 623 \\
\hline 2 & 22.6 & $15 \%$ OV-101 & Dynamic & 4 & 623 \\
\hline 3 & 19.0 & $30 \%$ OV-101 & Dynamic & 16 & 623 \\
\hline 4 & 22.0 & $20 \%$ OV-101 & Dynamic & 20 & 623 \\
\hline 5 & 24.9 & $20 \%$ OV -101 & Dynamic & 19 & 623 \\
\hline 6 & 24.0 & $0.25 \% \mathrm{SE}-30$ & Static & 19 & 623 \\
\hline $7^{*}$ & 21.6 & $0.25 \% \mathrm{SE}-30$ & Static & $5 \mathrm{~min}$ & 623 \\
\hline 8 & 22.6 & $0.50 \% \mathrm{SE}-30$ & Static & 17 & 605 \\
\hline
\end{tabular}

- Column 7 was etched dynamically as proposed by Franken et al. ${ }^{18}$.

\section{RESULTS AND DISCUSSION}

Qualitative analysis on packed columns

It was obvious from the results of preliminary experiments, and also from published data ${ }^{3}, 4$, that analyses under the given conditions (non-polar silicone stationary phases and the stated temperature) are considerably affected by the support material. The influence of support materials on the qualitative analysis was monitored by the retention times observed for $\mathrm{Ni}(\mathrm{DEDTC})_{2}$ relative to $n$-octacosane (Table IV). It was assumed that the retention time of the latter would not be affected by the support.

\section{TABLE IV}

RELATIVE RETENTION TIMES (r) AND ASYMMETRY COEFFICIENTS (As) OF Ni (DEDTC) $=$ FOUND AT $533^{\circ} \mathrm{K}$ ON VARIOUS SUPPORTS COATED WITH SE-30 STATIONARY PHASE

$r=t_{R, x}^{\prime} / t_{R, c_{28}}^{\prime}$, where $t_{R}^{\prime}=t_{R}-t_{M g}, x$ represents $N i(D E D T C)_{2}$ and $C_{28}$ represents $n$-octacosane; $A s=100 a / b$, where $a$ is the distance between the perpendicular from the top of the peak to the leading edge and $b$ is the distance between the perpendicular from the top and the descent edge, measured at one tenth of the peak height ${ }^{20}$.

\begin{tabular}{lllll}
\hline Support & Concentration of SE-30(\%) & As & $r$ & Column length $(\mathrm{m})$ \\
\hline Chromesorb G AW DMCS & 2 & 83 & 1.68 & 1.10 \\
Gas-Chrom P sil. & 3 & 86 & 1.68 & 0.55 \\
Gas-Chrom P sil. & 1 & 46 & 1.74 & 1.95 \\
Chromaton N AW HMDS & 3 & 93 & 1.75 & 0.55 \\
Chromosorb W sil. & 3 & 92 & 1.81 & 0.55 \\
Chezasorb AW HMDS & 3 & 71 & 1.81 & 0.55 \\
\hline
\end{tabular}

The support, owing to its polarity, increases the polarity of the non-polar coated packing material. Consequently, the relative retention time ( $r$ in Table IV) increases with increasing polarity of the support. Accordingly, the most suitable support for the separation of dialkyldithiocarbamates is Chromosorb G AW DMCS. The relative retention time decreases with increasing amount of stationary phase (for Gas-Chrom $P$ the relative retention time decreased from 1.74 to 1.68 when the amount 
of the stationary phase decreased from 3 to $1 \%$. In addition, as a result of the effect of the support material, the peaks become non-symmetrical (apart from the partition processes, adsorption phenomena also become manifest), making accurate quantitative analysis more difficult.

Fig. 1 shows that for the analysis of Ni(DEDTC) $)_{2}$ the least suitable support material is Chezasorb AW HMDS. It follows further (Table IV) from the asymmetry coefficient that the packing obtained by coating Gas-Chrom $P$ sil. with $1 \%$ of SE-30 is not suitable for the analysis of $\mathrm{Ni}(\mathrm{DEDTC})_{2}$.

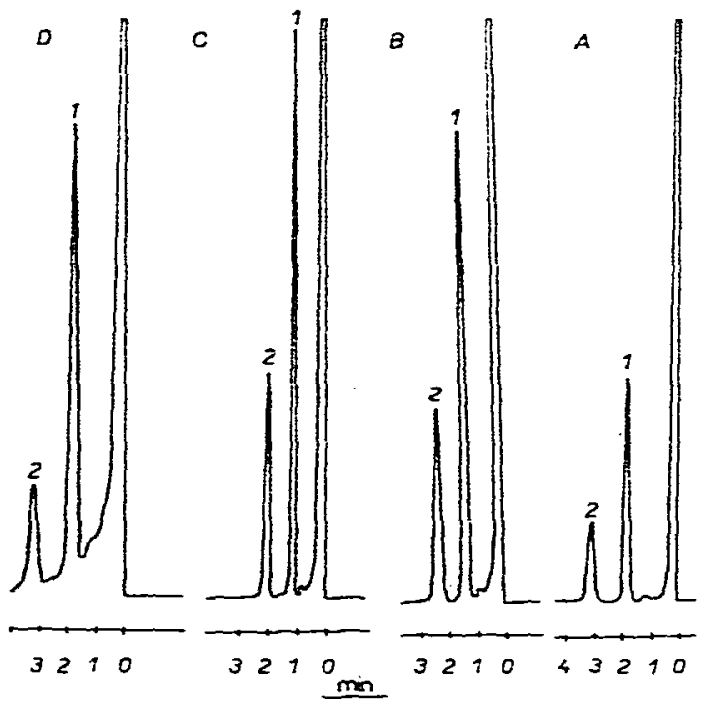

Fig. 1. Peak shapes of (1) $n$-octacosane and (2) Ni(DEDTC) $)_{2}$ obtained on columns packed with various silanized supports coated with $3 \%$ of SE-30. Column length, $0.55 \mathrm{~m}$. (A) Gas-Chrom $P$ sil.; (B) Chromaton N AW DMCS; (C) Chromosorb W sil.; (D) Chezasorb AW HMDS.

In agreement with the observations during thin-layer chromatography of dithiocarbamates" ${ }^{21} \mathrm{Zn(II)}$ bis(N,N-dialkyldithiocarbamates) gave less symmetrical gas chromatographic peaks than the corresponding nickel chelates. Consequently, the analysis of zinc dialkyldithiocarbamates is more dificult and the conditions must be selected more carefully than when nickel dithiocarbamates are to be analysed.

Peaks obtained from $\mathrm{Zn}(\mathrm{DEDTC})_{2}$ are more symmetrical than those from

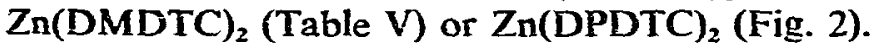

\section{TABLE V}

ASYMMETRY COEFFICIENTS (As) OF Zn(DMDTC), AND Zn(DEDTC), PEAKS OBTAINED ON VARIOUS SUPPORTS COATED WITH SE-30 STATIONARY PHASE AT $513^{\circ} \mathrm{K}$

Asymmetry coeficients calculated as in Table IV.

\begin{tabular}{lll}
\hline Support & $A s$ & \\
\cline { 2 - 3 } & $Z n(D M D T C)_{2}$ & $Z n(D E D T C)_{2}$ \\
\hline Chromosorb G AW DMCS & 66 & 91 \\
Gas-Chrom Q & 61 & 76 \\
Chromosorb W sil. & 50 & 66 \\
\hline
\end{tabular}




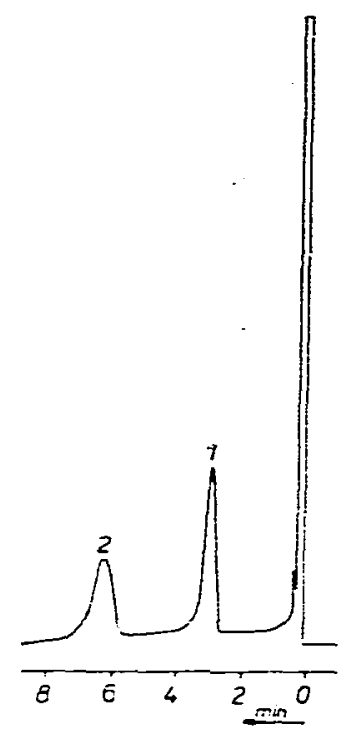

Fig. 2. Separation of (1) $\mathrm{Zn}(D E D T C)_{2}$ and (2) $\mathrm{Zn}$ (DPDTC), en a column packed with Gas-Chrom $Q$ coated with $3 \%$ of SE-30 at $513^{\circ} \mathrm{K}$ and $245.5 \mathrm{kPa}$.

For the analysis of $\mathrm{Zn}$ (II) bis(dialkyldithiocarbamates) the least polar packing was used (Fig. 3). The dashed peaks represent substances chromatographed separately. Under the given conditions, $\mathrm{Zn}(\mathrm{MIPDTC})_{2}$ and $\mathrm{Zn}(\mathrm{DEDTC})_{2}$ could not be separated.

Nickel and zinc dialkyldithiocarbamates were characterized by their retention times relative to $n$-octacosane and by their retention indices. Table VI gives the rel-

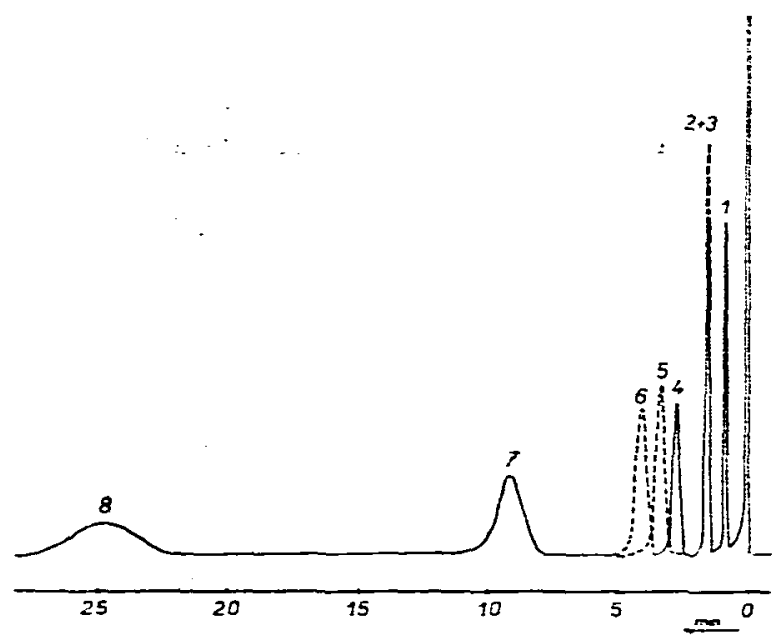

Fig. 3. Separation of Zn(II) bis(N,N-dialkyldithiocarbamates) on a column packed with Chromosorb G AW DMCS coated with $2 \%$ of SE-30 at $503^{\circ} \mathrm{K}$ and $147.3 \mathrm{kPa} .1, \mathrm{Zn}(\mathrm{DMDTC})_{2} ; 2+3, \mathrm{Zn}$ $(\text { DEDTC })_{2}+\mathrm{Zn}(\mathrm{MIPDTC})_{2} ; 4, \mathrm{Zn}(\mathrm{DIPDTC})_{2} ; 5, \mathrm{Zn}\left(\mathrm{DPDTC}_{2} ; 6, \mathrm{Zn}(\mathrm{DIBDTC})_{2} ; 7, \mathrm{Zn}(\mathrm{DBDTC})_{2}\right.$; $8, \operatorname{Zr}(\text { DPEDTC })_{2}$. 
TABLE VI

RELATIVE RETENTION TIMES (r)AND KOVĀTS RETENTIÓN INDICES ( $I)$ OF NICKEL(II) AND ZINC(II) DIALKYLDITHIOCARBAMATES OBTAINED ON GAS-CHROM $Q$ COATED WITH $3 \%$ OF SE-30

$r=t_{R, x}^{\prime} / t_{R, c_{23}}^{\prime}$

$I=100 z+200 \cdot \frac{\log t_{R_{. x}}^{\prime} / t_{R_{.}=}^{\prime}=}{\log t_{R_{*}=+z}^{\prime} / t_{R_{,}=}^{\prime}}$

where $z$ is the carbon number of the $n$-alkane eluted in front of a dialkyldithiocarbantate $x$ and $t_{R}^{\prime}=t_{R}-t_{M}$.

\begin{tabular}{|c|c|c|c|c|}
\hline \multirow[t]{2}{*}{ Alkyl group in ligand } & \multicolumn{2}{|c|}{$\mathrm{Ni}(\mathrm{II})$ ar $543^{\circ} \mathrm{K}$} & \multicolumn{2}{|c|}{$Z n(I I)$ at $515^{\circ} \mathrm{K}$} \\
\hline & $r$ & $\boldsymbol{I}$ & $r$ & $I$ \\
\hline Methyl & 1.08 & 2833 & 0.59 & 2548 \\
\hline Ethyl & 1.66 & 3007 & 0.67 & 2728 \\
\hline Propyl & 3.22 & 3277 & 1.79 & 3013 \\
\hline Isopropyl & 2.84 & 3229 & 1.52 & 2951 \\
\hline Butyl & 7.52 & 3618 & 4.63 & 3358 \\
\hline Isobutyl & 3.71 & 3332 & 2.06 & 3086 \\
\hline Pentyl & 17.57 & 3969 & 12.05 & 3706 \\
\hline
\end{tabular}

ative retention times and Kovats retention indices for zinc and nickel dialkyldithiocarbamates as measured on Gas-Chrom $Q$ coated with $3 \%$ of SE-30.

Kovats retention indices were used to calculate the increments corresponding to four $\mathrm{CH}_{2}$ groups:

$$
\Delta I_{\mathrm{ACH}_{2}}=I_{\mathrm{n}+\mathrm{L}}-I_{\mathrm{n}}
$$

where $n$ is the number of carbon atoms in the alkyl group linked to the nitrogen atom in the dithiocarbamate ligand. Table VII shows that the increments corresponding to four $\mathrm{CH}_{2}$ groups differ considerably from the expected value of 400 (ref. 22) and that their value increases with increasing number of carbon atoms in the ligand. The deviation from the expected value is connected with the electronegativity of the nitrogen atom in the dithiocarbamate ligand and the inductive effect of the alkyl group. As can be seen by comparison of the results obtained with $\mathrm{Zn}$ (II) and $\mathrm{Ni}$ (II) bis(N,N-

TABLE VII

DIFFERENCES IN INCREMENTS OF FOUR $\mathrm{CH}_{2}$ GROUPS CALCULATED FROM KOVÁTS RETENTION INDICES $(I)$

\begin{tabular}{|c|c|c|}
\hline $\mathrm{SI}_{4 \mathrm{CH}_{2}}$ & $N i$ & $Z_{n}$ \\
\hline 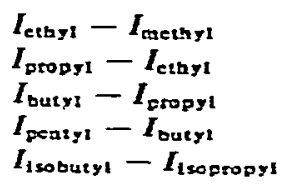 & $\begin{array}{l}174 \\
270 \\
341 \\
351 \\
103\end{array}$ & $\begin{array}{l}180 \\
285 \\
345 \\
348 \\
135\end{array}$ \\
\hline
\end{tabular}

- $\Delta I_{4 \mathrm{CH}_{2}}=I_{n+1}-I_{n}$, where $n$ represents the number of carbon atoms of the alkyl group linked to the nitrogen atom in the dithiocarbamate ligand. 


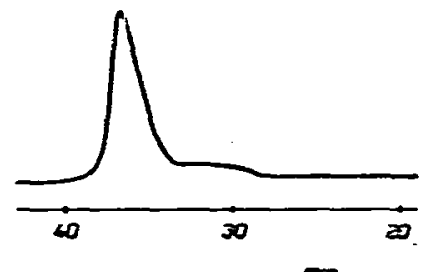

$+\operatorname{man}$

Fig. 4. Peak shape of Cu(DEDTC $)_{2}$ chromatographed on Gas-Chrom P sil. coated with $3 \%$ of SE-30 at $503{ }^{\circ} \mathrm{K}$.

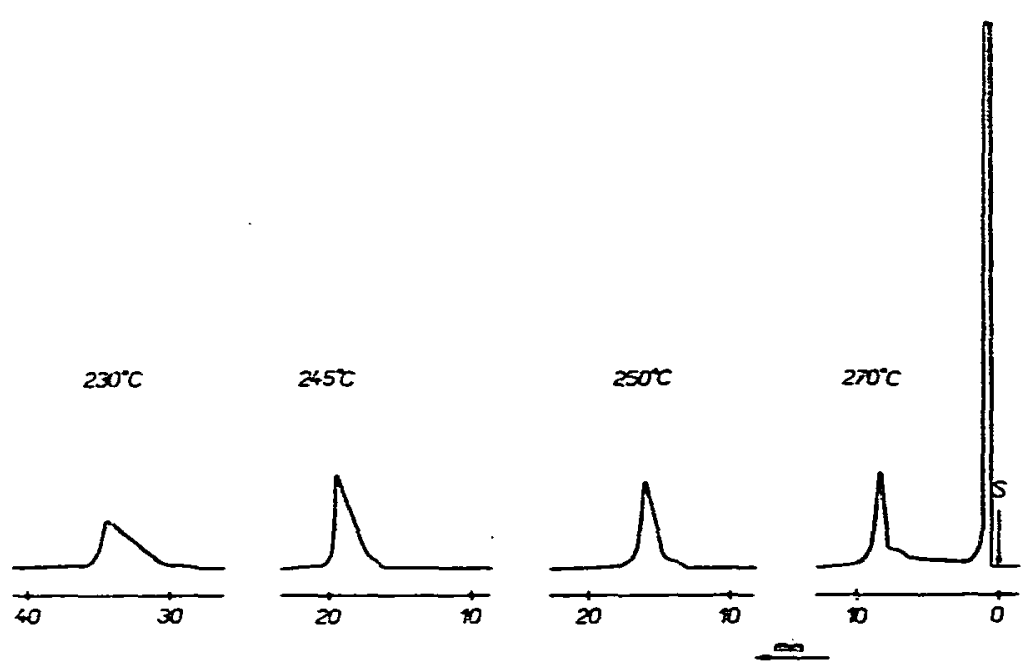

Fig. 5. Peak shapes of Cd(DEDTC), chromatographed on Gas-Cinrom P sil. coated with $3 \%$ of SE-30.

dialkyldithiocarbamates) (Table VII), the central atom does not have a substantial effect on the $\Delta I_{4 \mathrm{CH}_{2}}$ values.

In contrast to published data ${ }^{3-6}, \mathrm{Cu}(\mathrm{DEDTC})_{2}$ and Cd(DEDTC $)_{2}$ decomposed during the gas chromatographic analysis (Figs. 4 and 5). Cd(DEDTC) 2 also decomposed when chromatography was carried out at temperatures below the melting point (Fig. 5). Similar decomposition was also observed during the gas chromatography of $\mathrm{Cc}(\mathrm{DEDTC})_{2}$ -

Dimeric structures of $\mathrm{Zn}$ (II) and $\mathrm{Cd}(\mathrm{II})$ chelates $^{3,4}$ could not be detected under the conditions used.

\section{Quantitative analysis on packed columns}

The effect of the support material on the quantitative analysis of dithiocarbamates was tested by analysing standard solutions of $\mathrm{Ni}(\mathrm{DEDTC})_{2}$ and $\mathrm{Zn}(\mathrm{DMDTC})_{2}$ by the calibration graph method using the technique involving washing out the sample with a plug of solvent.

The calibration graph obtained for $\mathrm{Ni}(\mathrm{DEDTC})_{2}$ on Gas-Chrom $\mathrm{Q}$ coated with $2 \%$ of SE-30 is shown in Fig. 6 . The equations, calculated using the least- 


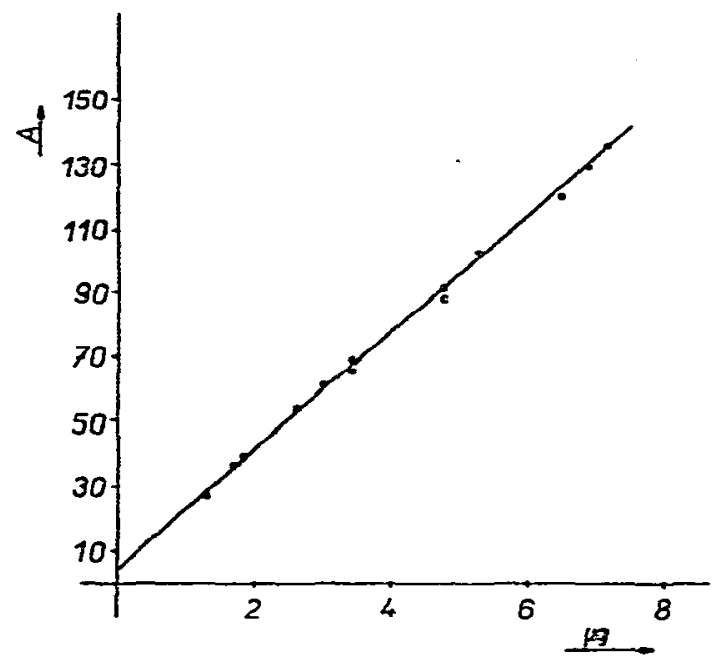

Fig. 6. Calibration graph for Ni(DEDTC) 2 obtained on Gas-Chrom $Q$ coated with $2 \%$ of SE-30. Peak area $(A)$ versus amount of $\mathrm{Ni}(\mathrm{DEDTC})_{2}$ injected.

squares method, of the calibration graphs obtained for Ni(DEDTC), analysed on columns packed with various supports are given in Table VIII. It follows that the most suitable packing materiais for the quantitative analysis of $\mathrm{Ni}(\mathrm{DEDTC})_{2}$ are those involving Gas-Chrom $Q$ and Chromosorb G AW DMCS as supports, as the calibration graphs pass through the origin.

\section{TABLE VIII}

EQUATIONS FOR CALIBRATION GRAPHS OBTAINED FOR Ni(DEDTC), CHROMATOGRAPHED ON VARIOUS SUPPORTS COATED WITH $3 \%$ OF SE-30

\begin{tabular}{ll}
\hline Support & Equation" \\
\hline Chromosorb W sil. & $y=-2.92+4.94 x$ \\
Gas-Chrom Q & $y=0.099+2.78 x$ \\
Chromosorb G AW DMCS & $y=-0.022+2.92 x$ \\
Gas-Chrom P sil. & $y=-3.50+3.90 x$ \\
Chromaton N AW HMDS & $y=-8.15+9.81 x$ \\
\hline
\end{tabular}

" $y$ is the peak area ( $\times 1000$ digits) and $x(\mu \mathrm{g})$ the amount of Ni(DEDTC $)_{2}$ injected.

Quantitative analyses of $\mathrm{Zn(1I)}$ dialkyldithiocarbamates require much more careful selection of high-quality supports, such as Chromosorb G AW DMCS, GasChrom $Q$ and Chromosorb W sil. Zn(DMDTC) $)_{2}$ (Ziram) was chosen as the test compound.

The equations for the calibration graphs for $\mathrm{Zn}(\mathrm{DMDTC})_{2}$, obtained in a manner similar to that used for $\mathrm{Ni}(\mathrm{DEDTC})_{2}$, are given in Table IX. A comparison of the results in Tables VIII and IX shows that in the quantitative analysis of $\mathrm{Zn}(\mathrm{DMDTC})_{2}$ a considerably greater systematic error than with $\mathrm{Ni}(\mathrm{DEDTC})_{2}$ occurs.

Table IX indicates that the systematic error of the determination decreases with decreasing separation temperatures. 
TABLE IX

EQUATIONS FOR CALIBRATION GRAPHS OBTAINED FOR Zn(DMDTC), CHROMATOGRAPHED ON VARIOUS SUPPORTS COATED WITH $3 \%$ OF SE-30

\begin{tabular}{lcl}
\hline Support & Column iemperature $\left.{ }^{\circ} \mathrm{K}\right)$ & Equation \\
\hline Chromosorb G AW DMCS & 503 & $y=-16.9+20.0 x$ \\
Chromosorb G AW DMCS & 493 & $y=-8.3+13.2 x$ \\
Gas-Chrom Q & 503 & $y=-17.1+15.4 x$ \\
Chromosorb W sil. & 493 & $y=-51.3+50.8 x$ \\
\hline
\end{tabular}

$y$ is the peak area ( $\times 1000$ digits) and $x(\mu \mathrm{g})$ the amount of $\mathrm{Zn}(\mathrm{DMDTC})_{2}$ injected.

\section{Capillary column gas chromatography}

Metai capillary columns, coated with a non-polar stationary phase, have a high activity ${ }^{23}$. Glass capillary columns offer certain possibilities for the analysis of metal chelates by gas chromatography, as the surface of glass, after suitable modification, can be rendered sufficiently inerti ${ }^{24}$. Glass capillary columns were prepared as previously described ${ }^{17}$.

For practical reasons, a carrier gas velocity of $c a .50 \mathrm{~cm} / \mathrm{sec}$ was used, which is approximately five times higher than the optimal velocity.

The quality of the capillary columns was tested by means of the Golay equation $^{2 s}$ for $n$-octacosane, and by determining the coefficient of asymmetry for the peak of $\mathrm{Ni}(\mathrm{DEDTC})_{2}$.

A plot of $H$ versus $\bar{u}$ for three capillary columns coated with a silicone phase is given in Fig. 7, which shows that the best column is that coated by the static method ${ }^{19}$ using a $0.25 \%$ solution of SE-30. The column coated with a $0.5 \%$ solution of SE-30 is less efficient, possibly because the layer of the phase is twice as thick. The mode of coating (static or dynamic) under the given conditions does not appear to affect substantially the quality of the capillary columns (columns 1 and 2, Fig. 7).

Golay equations calculated for columns 3,6 and 8 (Table III) can be written as $H=B / \bar{u}+C \bar{u}$ :

Column 8: $\quad H=0.267 / \bar{u}+0.0029 \bar{u}$

Column 6: $\quad H=0.218 / \bar{u}+0.00296 \bar{u}$

Column 3: $\quad H=0.197 / \bar{u}+0.00207 \bar{u}$

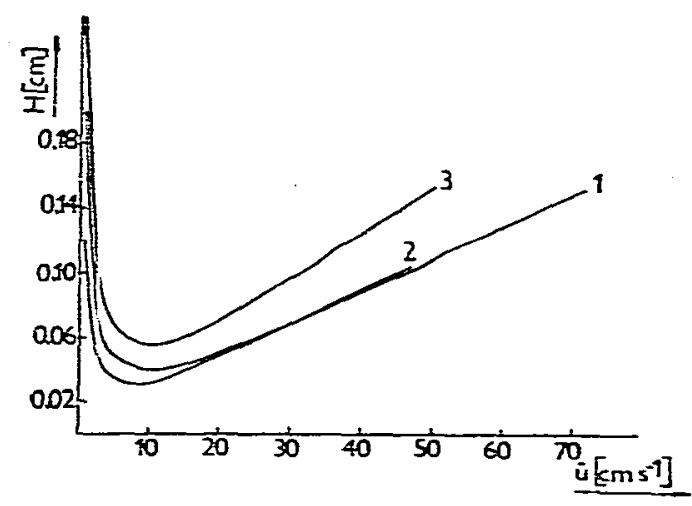

Fig. 7. Dependence of the height equivalent to a theoretical plate $(H)$ on the mean carrier gas (nitrogen) velocity obtained for three capillary columns. Column: (1) No. 3; (2) No. 6; (3) No. 8. 
It follows from these equations and from Fig. 7 that the quality of the columns is considerably affected by the resistance towards mass transfer, which manifests itself mainly at high carrier gas velocities. This resistance has its origin in the heterogeneity of the wall surface of the glass capillary columns (after etching with hydrogen chloride, crystals of sodium chloride are formed on the surface of the wall). With substances that require high carrier gas velocities, the limiting factor in the use of etched glass capillary columns is this resistance towards the mass transfer.

Another factor that affects the quality of the glass columns, apart from the sodium chloride crystals, are the silanol groups, formed during the process of etching as a result of the reaction of glass with hydrogen chloride. The silanol groups make the peak asymmetry of $\mathrm{Ni}(\mathrm{DEDTC})_{2}$ more pronounced.

Table $X$ shows the asymmetry coefficients, capacity ratios and relative retention times measured on capillary columns for $n$-octacosane and Ni(DEDTC) ${ }_{2}$. It is obvious from the relative retention times that the analysis of $\mathrm{Ni}(\mathrm{DEDTC})_{2}$ on capillary columns is affected also by other factors in addition to the distribution coeficient. The asymmetry coefficients show that $\mathrm{Ni}(\mathrm{DEDTC})_{2}$ exhibits tailing on all columns examined except column 7. The main cause of this tailing is the adsorption of $\mathrm{Ni}(\mathrm{DEDTC})_{2}$ on the glass surface. It follows from the asymmetry coefficient for column $7(A s=161)$ that the applied temperature of the analysis $\left(501^{\circ} \mathrm{K}\right)$ is not high enough [the melting point of $\mathrm{Ni}(\mathrm{DEDTC})_{2}$ is $508^{\circ} \mathrm{K}$ ] because, in order to convert the substance into the gaseous state, the heat of melting, in addition to the heat of evaporation, must be supplied. As these two phenomena do not occur fast enough, the elution peak is non-symmetrical and appears overloaded.

TABLE X

ASYMMETRY COEFFICIENTS ( $A s)$, CAPACITY FACTORS $(k)$, EFFICIENCY [No. OF PLATES, $r$; AND $r / m$ ] AND RELATIVE RETENTION TIMES $(r)$ OF Ni(DEDTC) OBTAINED AT $529^{\circ} \mathrm{K}$

\begin{tabular}{|c|c|c|c|c|c|c|}
\hline Column & Compound & $A s$ & $k$ & $\pi$ & $n / m$ & $r$ \\
\hline 1 & $\mathrm{Ni}(\mathrm{DEDTC})_{2}$ & 38 & 21.9 & 16760 & $\begin{array}{l}533 \\
650\end{array}$ & 1.66 \\
\hline 2 & $\begin{array}{l}\text { Ni(DEDTC), } \\
C_{23}\end{array}$ & $\overrightarrow{40}$ & $\begin{array}{l}13.2 \\
21.7 \\
12.75\end{array}$ & $\begin{array}{r}20420 \\
7950 \\
8550\end{array}$ & $\begin{array}{l}630 \\
352 \\
378\end{array}$ & 1.70 \\
\hline 3 & $\begin{array}{l}\mathrm{Ni}(\mathrm{DEDTC})_{2} \\
\mathrm{C}=\mathrm{s}\end{array}$ & $\begin{array}{l}89 \\
-\end{array}$ & $\begin{array}{l}37.5 \\
22.6\end{array}$ & $\begin{array}{l}11360 \\
12500\end{array}$ & $\begin{array}{l}598 \\
657\end{array}$ & 1.65 \\
\hline 4 & $\begin{array}{l}\mathrm{Ni}(\mathrm{DEDTC})_{2} \\
\mathrm{C}_{25}\end{array}$ & 45 & $\begin{array}{l}47.75 \\
28.0\end{array}$ & $\begin{array}{l}11930 \\
16250\end{array}$ & $\begin{array}{l}540 \\
740\end{array}$ & 1.70 \\
\hline 6 & $\begin{array}{l}\text { Ni(DEDTC })_{2} \\
\mathrm{C}_{25}\end{array}$ & 54 & $\begin{array}{r}13.0 \\
7.1\end{array}$ & $\begin{array}{l}13670 \\
16780\end{array}$ & $\begin{array}{l}570 \\
700\end{array}$ & 1.83 \\
\hline $7^{*}$ & $\begin{array}{l}\mathrm{Ni}(\mathrm{DEDTC})_{2} \\
\mathrm{C}_{23}\end{array}$ & 161 & $\begin{array}{l}18.7 \\
11.3\end{array}$ & $\begin{array}{r}19320 \\
-37450\end{array}$ & $\begin{array}{r}895 \\
1734\end{array}$ & 1.63 \\
\hline
\end{tabular}

- Measured at $501^{\circ} \mathrm{K}$.

We have found that the value of the parameter $C$ for a column etched by the dynamic method is about half of that for a column etched in the static manner. The value of $C$ for columns etched statically is $0.002 \mathrm{sec}$. For column $T$ (etched dynamically for $5 \mathrm{~min}$ at $625^{\circ} \mathrm{K}$ ); a value of $C=0.001 \mathrm{sec}$ was found and thus the highest efficiency (plates per metre, Table X) for Ni(DEDTC) 2 was found for this column. 


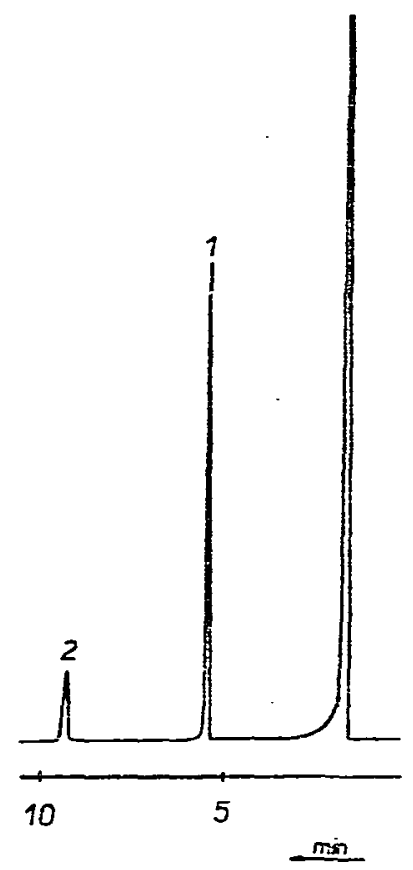

Fig. 8. Separation of (1) $n$-octacosane and (2) Ni(DEDTC), on a glass capillary column (column No. 1) at $543^{\circ} \mathrm{K}$ and a mean carrier gas (nitrogen) velocity of $42 \mathrm{~cm} / \mathrm{sec}$.

The separation of Ni(DEDTC) $)_{2}$ and $n$-octacosane on capillary column 1 is shown in Fig. 8.

Fig. 9 shows a chromatogram of a mixture of $\mathrm{Ni(DMDTC})_{2}, \mathrm{Ni}(\mathrm{DEDTC})_{2}$, $\mathrm{Ni}(\mathrm{DPDTC})_{2}, \mathrm{Ni}(\mathrm{DIPDTC})_{2}, \mathrm{Ni}(\mathrm{DBDTC})_{2}, \mathrm{Ni}(\mathrm{DIBDTC})_{2}$ and $\mathrm{Ni}(\mathrm{DPEDTC})_{2}$ on a capillary column coated with OV-101 as stationary phase at $543^{\circ} \mathrm{K}$. Dashed peaks represent substances chromatographed separately.

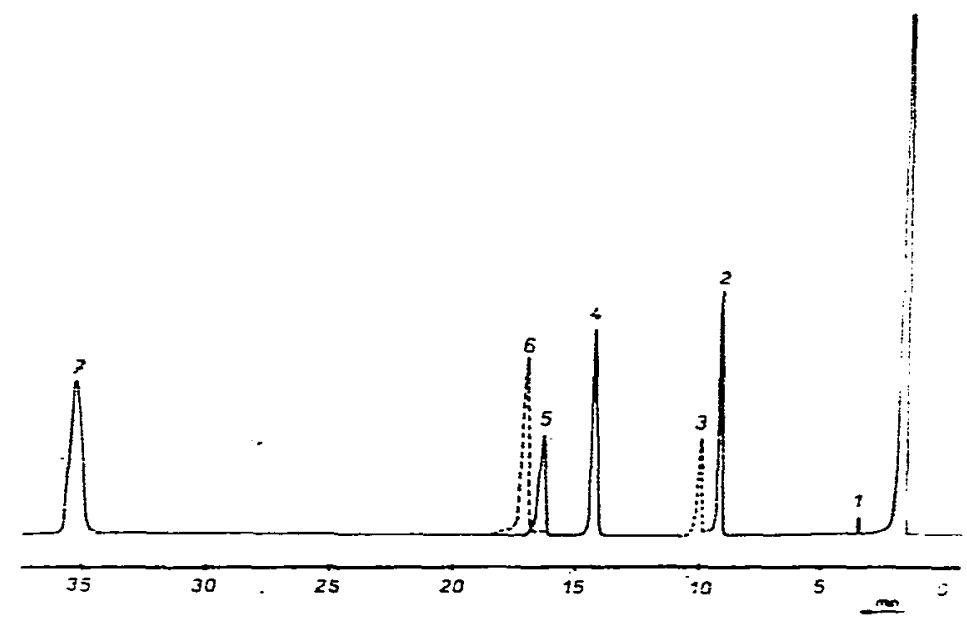

Fig. 9. Separation of $\mathrm{Ni}(\mathrm{II})$ bis(N,N-dialkyldithiocarbamates) on a glass capillary column (column No. 1) at $543^{\circ} \mathrm{K}$ and a mean carrier gas (nitrogen) velocity of $42 \mathrm{~cm} / \mathrm{sec}$. 1, Ni(DMDTC) $; 2$, $\mathrm{Ni}(\mathrm{DEDTC})_{2} ; 3$, Ni(MIPDTC $)_{2} ; 4, \mathrm{Ni}(\mathrm{DIPDTC})_{2} ; 5, \mathrm{Ni}(\mathrm{DPDTC}): ; 6, \mathrm{Ni}(\mathrm{DIBDTC})_{2} ; 7, \mathrm{Ni}$ (DBDTC) . 
Mass spectrometry of nickel(II) and zinc(II) bis( $N, N$-dialkyldithiocarbamates)

The mass spectra of a number of N,N-dialkyldithiocarbamato complexes of various metals have been reported $d^{2,7-16}$. Only few analyses of fragmentation patterns have been attempted, notably for tris(N,N-dimethyldithiocarbamates) of $\mathrm{Cr}$, In ${ }^{8}, \mathrm{Fe}$, $\mathrm{Co}, \mathrm{Ru}$ and $\mathrm{Rh}^{9}$; for tris(N,N-diethyldithiocarbamates) of $\mathrm{Cr}, \mathrm{Fe}, \mathrm{Co}, \mathrm{Ru} \mathrm{Tl}^{9}$ and $\mathrm{As}^{10}$; for various trisdithiocarbamato complexes of $\mathrm{As}, \mathrm{Sb}$ and $\mathrm{B} \mathrm{i}^{10}$; for halobis(dialkyldithiocarbamates) of $\mathrm{As}, \mathrm{Sb}, \mathrm{Bi}^{11}$ and $\mathrm{Fe}^{9}$; and for tetrakisdihalobis- and diphenylbis(N,N-diethyldithiocarbamates) of $\mathrm{Sn}(\mathrm{IV})^{16}$. Mass spectral data on some bis(N,N-dialkyldithiocarbamates) of $\mathrm{Cu}^{7}, \mathrm{Zn}^{7,12,13}$ and $\mathrm{Ni}^{2},{ }^{14}$ and for monoalkyl- and dialkyldithiocarbamates of $\mathrm{Na},\left[\mathrm{S}_{2} \mathrm{CN}\left(\mathrm{CH}_{3}\right)_{2}\right]_{2}$ and $\left[\mathrm{S}_{2} \mathrm{CN}\left(\mathrm{C}_{2} \mathrm{H}_{5}\right)_{2}\right]_{2}$ have been published ${ }^{9}, 12$.

Of the $\mathrm{Zn}(\mathrm{II})$ bis(N,N-dialkyldithiocarbamate) series, mass spectra of only the permethyl ${ }^{12,15}$ and the perethyl compounds ${ }^{7,13}$ have been reported. The mass spectrum of $\mathrm{Ni}$ (II) bis(N,N-diethyldithiocarbamate) ${ }^{2}$ and the aegative-ion mass spectra of the perethyl-, per-n-propyl- and per-n-butyldithiocarbamate derivatives- of $\mathrm{Ni}(\mathrm{II})^{14}$ are the only data that have been presented to date on $\mathrm{Ni}(\mathrm{II})$ bis(N,N-dialkyldithiocarbamates).

As we had many homologues available, we decided to investigate in detail the electron-impact (positive-ion) mass spectra of all of the $\mathrm{Ni}(\mathrm{II})$ and $\mathrm{Zn}(\mathrm{In})$ bis(N,Ndialkyldithiocarbamates) listed in Table I.

From the mass spectra of these compounds, we derived a rationale for a general fragmentation scheme, as presented in Fig. 10. Although aiternative pathways are possible for the genesis of a number of ions, metastable transitions support the formation of the major ions in this scheme. In addition to these fragment ions, the following ions may be formed via various pathways:

$$
\begin{aligned}
& h-1:(\mathrm{R}-1)=\stackrel{+}{\mathrm{N}}=\mathrm{C}=\mathrm{S} \\
& r:\left(\mathrm{M}-\mathrm{CS}_{2}-\mathrm{H}^{\cdot}\right)^{+} \\
& s: \mathrm{CS}_{2} \pm(m / e 76) \\
& t-1:(\mathrm{R}-1)+ \\
& t-2:(\mathrm{R}-2)^{+} \\
& u: \mathbf{R}_{\mathbf{2}} \mathrm{N}^{+} \\
& w=q-R:\left[\begin{array}{lll} 
& Y \\
R-N=C & \vdots \\
& & S
\end{array}\right]^{+} \\
& w-32:[R-N=C=Y] \text { : } \\
& x=c-90:\left[\begin{array}{c}
\mathrm{R}-\mathrm{Y}-\mathrm{C}-\mathrm{NR}_{2} \\
\| \\
\mathrm{S}
\end{array}\right]^{ \pm} \\
& y: \stackrel{+}{\mathrm{N}} \mathrm{H}=\mathrm{CH}_{2} \\
& y-2: \mathrm{R} \stackrel{+}{\mathrm{N}} \equiv \mathbf{C H} \\
& \mathrm{CS}: \text { : }(m / e \text { 44) } \\
& \mathrm{YS}_{2}+: m / e 122(\mathrm{Y}=\mathrm{Ni}) \text { and } m / e 128(\mathrm{Y}=\mathrm{Zn})
\end{aligned}
$$




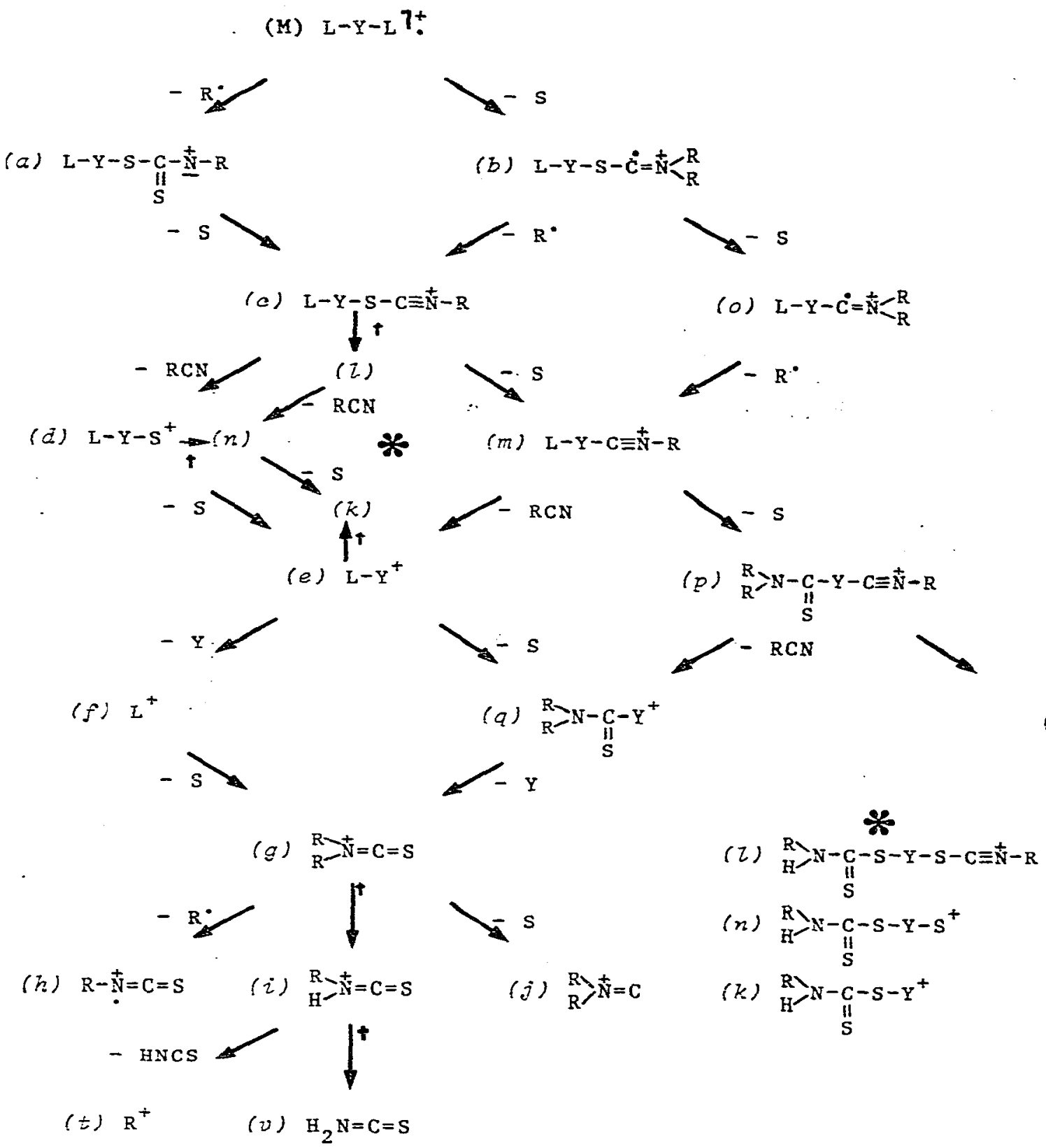

Fig. 10. Proposed fragmentation pathways of $\mathrm{Ni}(\mathrm{II})$ and $\mathrm{Zn}(\mathrm{II})$ bis(N,N-dialkyldithiocarbamates).

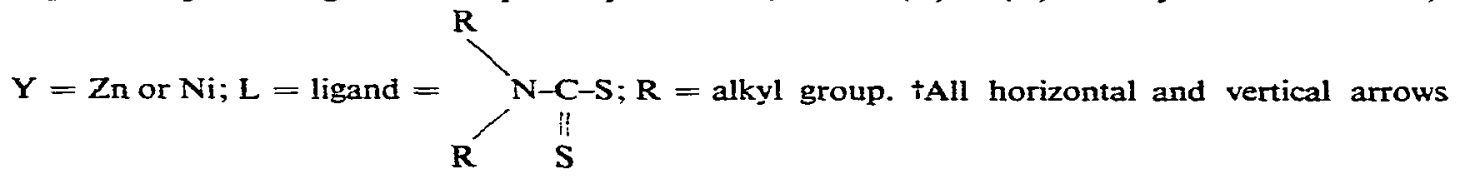
depict the Ioss of an olefinic molecule, $R-1$. All diagonal arrows from left to right indicate the loss of a molecule of $\mathrm{S}$. Diagonal arrows from right to left represent losses as indicated. Note: the Y(MIPDTC): complexes yield two series of fragment ions. 
Although structures of the fragments are given, it should be borne in mind that many isomeric and mesomeric structures are possible. The molecular ion $\mathbf{M}$, for example, can be represented as follows:

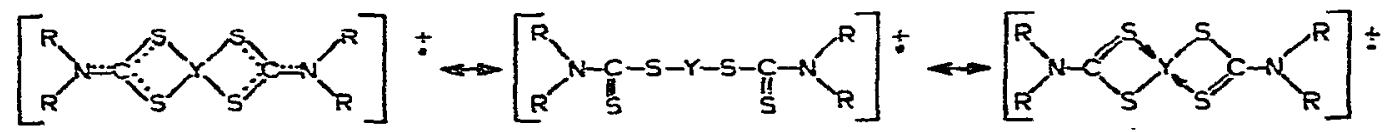

In all instances characteristic isotopic clusters appear for the $Y$-containing ions $(\mathrm{M}, a, b, c, d, e, k, l, m, n, o, p, q, r, w, x, z)$. Moreover, $e, q$ and $f$ appear in clusters -2 to +4 a.m.u. Especially for more highly substituted compounds, alkyl fragment series are abundant ( $m / e 57,55,43,41)$. The electron-impact mass spectra of $\mathrm{Ni}(\mathrm{II})$ and $\mathrm{Zn}$ (II) bis(N,N-dialkyldithiocarbamates) are summarized in Tables XI and XII, respectively (full spectra are available on requcst from P.A.L.). In these tables, only the most abundant peaks from the isotopic clusters are included, corresponding to ${ }^{58} \mathrm{Ni}$ - and ${ }^{64} \mathrm{Zn}$-containing ions, respectively. Above mass 100 , the intensities of the ions omitted in Tables XI and XII are generally less than $2 \%$ of that of the base peak, with the following exceptions. Table XI: Ni(DMDTC),$y=56 \% ; \mathrm{Ni}(\mathrm{DHPDTC})_{2}, z=$

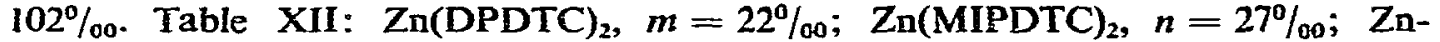
(DMDTC),$q=27 \%$. Moreover $\mathrm{NiS}_{2}{ }^{+}(\mathrm{m} / \mathrm{e} 122)$ occurs in the spectra of $\mathrm{Ni}-$

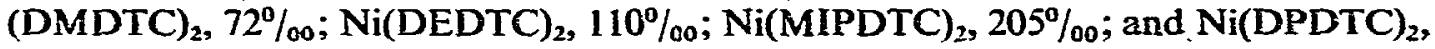
$25 \%$. $\mathrm{ZnS}_{2}+(m / e 128)$ in found only in the spectrum of $\mathrm{Zn}(\mathrm{DEDTC})_{2}, 89 \%$. Fig. 10 is rcdrawn for nickel and zinc complexes in Figs. 11 and 12, respectively, indicating the major fragmentation pathways for these classes of compounds. Pathways confirmed by metastable decompositions are indicated.

\section{Discussion of mass spectra}

From Tables XI and XII and Figs. 11 and 12, difierent fragmentation patterns appear for $\mathbf{N i}$ (II) and $\mathbf{Z n ( I I )}$ chelates. The molecular ions $\mathbf{M}$ of nickel derivatives are more abundant than those of zinc. Because the relative intensities of the molecular ions reflect the bond strengths of the $\mathrm{YS}_{4}$ coordination cores, this indicates that complexes of nickel are more stable than those of zinc. Owing to the lower relative intensities of the molecular ions, the primary fragmentation products of the zinc complexes are less abundant than the corresponding nickel fragment ions. However, the formation of ions $a, c, d$ and $f$ is clearly favoured with zinc derivatives over nickel derivatives. In the spectra of the nickel complexes, ions $b, e+1, w$ and the cluster around $q$ are relatively more abundant than in the zinc bis(dialkyldithiocarbamate) spectra. Ions $g, h, i, s, u, v$ and the clusters of $t$ and $y$ are the most abundant fragment ions in all instances.

In general, the intensity of the ions in the high mass region decreases predictably with increasing size of $n$-alkyl substituents, per-pentyl compounds being anomalous. The isopropyl and isobutyl derivatives of nickel bis(dithiocarbamates) fragment much more easily than the n-alkyl derivatives. With zinc bis(dialkyldithiocarbamates) this effect is less evident. 
TABLE XI

RELATIVE INTENSITIES (\%) OF MAJOR IONS (ABOVE $m / e$ 40) IN THE MASS SPECTRA OF Ni(II) BIS(N,N-DIALKYLDITHIOCARBAMATES)

Terms in parentheses represent coincident ions. Superscripts: ${ }^{+2}=2$ a.m.u. higher; ${ }^{+1}=1$ a.m.u. higher; ${ }^{-1}=1$ a.m.u. lower; ${ }^{-2}=2$ a.m.u. lower. ? = Not measured.

\begin{tabular}{|c|c|c|c|c|c|c|c|c|c|c|c|c|c|c|}
\hline Compound & $M$ & $b$ & $e$ & $e+1$ & $j$ & $g$ & $h-1$ & $h$ & $i$ & $i$ & $k$ & $m$ & $n$ & $o$ \\
\hline $\begin{array}{l}\mathrm{Ni}(\mathrm{DMDTC})_{2} \\
\mathrm{Ni}(\mathrm{DEDTC})_{2}\end{array}$ & $\begin{array}{l}671 \\
742\end{array}$ & $\begin{array}{l}204 \\
134\end{array}$ & $\begin{array}{l}406 \\
225\end{array}$ & $\begin{array}{r}96 \\
260\end{array}$ & $\begin{array}{r}62^{+1} \\
140^{-2}\end{array}$ & $\begin{array}{r}1000 \\
915\end{array}$ & $\begin{array}{r}109 \\
68\end{array}$ & $\begin{array}{r}273 \\
61\end{array}$ & $\begin{array}{r}54 \\
1000\end{array}$ & 122 & $\begin{array}{l}119^{-1} \\
147^{-1}\end{array}$ & $\begin{array}{l}86 \\
59\end{array}$ & $\begin{array}{r}10^{-1} \\
134^{-1}\end{array}$ & $\begin{array}{l}89 \\
53\end{array}$ \\
\hline $\mathrm{Ni}(\mathrm{MIPDTC})_{2}=$ & 375 & 92 & 269 & 303 & $67^{+1}$ & 750 & $\begin{array}{r}35 \\
(a)\end{array}$ & $\begin{array}{r}99 \\
251\end{array}$ & $\begin{array}{r}31 \\
707\end{array}$ & 48 & $\begin{array}{r}12^{-1} \\
129^{-1}\end{array}$ & $\begin{array}{r}2 \\
80\end{array}$ & $61^{2^{-1}}$ & 31 \\
\hline $\mathrm{Ni}(\mathrm{DPDTC})_{2}$ & 469 & 113 & 124 & 115 & $67^{-1}$ & 503 & (u) & 37 & 571 & 27 & $38^{-1}$ & 18 & 6 & 18 \\
\hline $\mathrm{Ni}(\mathrm{DIPDTC})_{2}$ & 219 & 90 & 58 & 43 & 8 & $271^{+1}$ & (u) & 529 & 298 & 37 & 21 & 8 & $7^{+1}$ & - \\
\hline $\mathrm{Ji}(\mathrm{DBDTC})_{2}$ & 425 & 82 & 64 & 57 & $52^{+}$ & 249 & 56 & 49 & 411 & 93 & $(f+1)^{-1}$ & 5 & $1^{-1}$ & 7 \\
\hline $\mathrm{Ni}(\text { DIBDTC })_{2}$ & 301 & 79 & 76 & 18 & $52^{+1}$ & 121 & 41 & 72 & 306 & 28 & $(f+1)^{-1}$ & 3 & $2^{-1}$ & 5 \\
\hline $\mathrm{Ni}(D P E D T C)_{2}$ & 751 & 219 & 78 & 28 & $45^{+1}$ & 253 & 33 & 39 & 406 & 195 & 13 & $4^{+2}$ & 7 & 7 \\
\hline $\mathrm{Ni}(\mathrm{DHDTC})_{2}$ & 255 & 56 & 19 & 16 & $44^{+1}$ & 253 & 39 & 28 & 237 & 278 & - & $6^{+2}$ & - & 2 \\
\hline Ni(DHPDTC $)_{2}$ & 158 & 16 & 4 & 40 & 31 & 182 & 40 & 5 & 149 & 504 & 7 & - & - & - \\
\hline $\mathrm{Ni}(\mathrm{DODTC})_{2}$ & 42 & 8 & - & 3 & 9 & 61 & 23 & 2 & 31 & 283 & 2 & - & 9 & - \\
\hline
\end{tabular}

- Upper row corresponds to ions containing more methyl than isopropyl groups and the lower row to the opposite situation.

\section{TABLE XII}

RELATIVE INTENSITIES (\%) OF MAIN IONS (ABOVE m/e 40) IN THE MASS SPECTRA OF Zn(II) BIS(N,N-DIALKYLDITHIOCARBAMATES)

Notes as in Table XI.

\begin{tabular}{|c|c|c|c|c|c|c|c|c|c|c|c|c|}
\hline Compound & $M$ & $a$ & $b$ & $c$ & $d$ & $e$ & $f$ & $g$ & $h-l$ & $h$ & $i$ & $j$ \\
\hline $\mathrm{Zn}(\mathrm{DMDTC})_{2}$ & 168 & 7 & 4 & 4 & 42 & 91 & 243 & 1000 & 431 & 301 & 81 & 270 \\
\hline $\mathrm{Zn}(\mathrm{DEDTC})_{2}$ & 140 & 18 & - & 8 & 85 & 100 & 218 & 724 & 386 & 781 & 861 & 66 \\
\hline $\mathrm{Zn}(\mathrm{MIPDTC})_{2}$ & 161 & $\overline{16}$ & $4^{-1}$ & $\overline{18}$ & 66 & 81 & 110 & 237 & $\begin{array}{l}106 \\
(u)\end{array}$ & $\begin{array}{r}50 \\
849\end{array}$ & $\begin{array}{r}13 \\
643\end{array}$ & 34 \\
\hline $\mathrm{Zn}(\mathrm{DPDTC})_{2}$ & 121 & 9 & $11^{-1}$ & 28 & 63 & 91 & 118 & 287 & (u) & 119 & 248 & 99 \\
\hline $\mathrm{Zn}(\mathrm{DIPDTC})_{2}$ & 34 & 9 & - & 7 & 14 & 52 & 30 & 59 & (u) & 499 & 183 & - \\
\hline $\mathrm{Zn}(\mathrm{DBDTC})=$ & 23 & 1 & $5^{-1}$ & 3 & 11 & 18 & 33 & 83 & 52 & 546 & 267 & 177 \\
\hline $\mathrm{Zn}($ DIBDTC $)=$ & 43 & - & $6^{-1}$ & 32 & 31 & 82 & 56 & 137 & 58 & 198 & 156 & 74 \\
\hline $\mathrm{Zn}(\mathrm{DPEDTC})_{2}$ & 56 & - & $14^{-1}$ & 9 & 28 & 46 & 48 & 175 & 23 & 39 & 123 & 348 \\
\hline
\end{tabular}

- Upper row corresponds to ions containing more methyl than isopropyl groups and the lower row to the opposite situation.

The occurrence of the $\left[\mathrm{Zn}(\mathrm{DEDTC})_{2}\right]_{2}$ dimer in the gas phase has been reported $^{13}$ : the ion $2 \mathrm{M}$ had an intensity of $1 \%$ relative to $\mathbf{M}$ in the mass spectrum. In contrast to these findings, we could not detect any ions above the isotopic cluster of $M$ (under the conditions applied, all ions with an intensity higher than $0.01 \%$ of the base peak were detected). In the low mass region, alkyl $(m / e 43,57, \ldots, t)$ and alkenyl $\left(m / e^{4} 41,55, \ldots, t-2\right)$ ions are prominent. The intensity of $\mathrm{HNR}^{+}$ions, as reported for perethyl compounds ${ }^{10}$, in which case this ion coincides with $\mathrm{CS} \div$ at $m / e 44$, is higher 


\begin{tabular}{|c|c|c|c|c|c|c|c|c|c|c|c|c|c|c|c|c|}
\hline$p$ & $q-2$ & $q-1$ & $q$ & $s$ & $t-2$ & $t$ & $u$ & $v$ & $w$ & $x$ & $y-2$ & $y$ & $m / e 57$ & mie 55 & $m / e 43$ & $m / e 41$ \\
\hline 79 & 71 & 87 & 187 & 203 & $?$ & $?$ & 812 & 70 & 138 & 74 & 390 & & $128^{+1}$ & $(j)$ & & 1 \\
\hline 117 & 60 & 236 & 161 & 127 & $?$ & $?$ & 610 & 943 & 140 & 27 & 162 & 101 & $(y)^{+1}$ & $110^{+1}$ & $218^{+1}$ & $102^{+1}$ \\
\hline $\overrightarrow{50}$ & 49 & 237 & 174 & 129 & $\begin{array}{l}? \\
588\end{array}$ & $\stackrel{?}{1000}$ & 502 & 60 & $\begin{array}{r}51 \\
274\end{array}$ & $\begin{array}{l}22 \\
29\end{array}$ & $\begin{array}{r}397 \\
40\end{array}$ & $\underset{(a)}{52}$ & $04+1$ & $169^{+1}$ & $(t)$ & $(t-2)$ \\
\hline 64 & 51 & 92 & 101 & 27 & 398 & 1000 & 272 & 318 & 50 & 28 & 74 & 54 & $72^{+1}$ & $26^{+1}$ & $(t)$ & $(t-2)$ \\
\hline 14 & - & 17 & 35 & 650 & 736 & 1000 & 206 & 809 & $14^{+1}$ & - & 105 & 188 & 280 & 89 & $(t)$ & $(t-2)$ \\
\hline 31 & 48 & 47 & 40 & 75 & 198 & 1000 & 191 & 199 & 49 & 21 & 81 & 75 & $(t)$ & $(t-2)$ & 103 & 598 \\
\hline 33 & 35 & 69 & 61 & 26 & 191 & 1000 & 98 & 78 & 60 & 6 & 84 & 33 & $(t)$ & $(t-2)$ & 89 & 55 \\
\hline 32 & 56 & 32 & 33 & 57 & 234 & 866 & 229 & 115 & 48 & 69 & 101 & 104 & 20 & 178 & 1000 & 632 \\
\hline 11 & 9 & 10 & 6 & 13 & 108 & 418 & 105 & 104 & 29 & 26 & 141 & 242 & 269 & 448 & 1000 & 801 \\
\hline - & 10 & 12 & 6 & 741 & $163^{+1}$ & 58 & 184 & 98 & 14 & 12 & 412 & 671 & 714 & 981 & 1000 & 805 \\
\hline _- & 1 & 2 & - & 282 & $60^{+1}$ & 12 & 67 & 15 & - & 8 & 199 & 803 & 508 & 315 & 1000 & 491 \\
\hline
\end{tabular}

\begin{tabular}{rlllllllllll}
$k$ & $s$ & $t-2$ & $t$ & $u$ & $v$ & $y-2$ & $y$ & $m / e 57$ & $m / e 55$ & $m / e 43$ & $m / e 41$ \\
\hline 4 & 336 & $?$ & $?$ & 641 & 50 & 801 & $(u)$ & $(j-1)^{-1}$ & 23 & 204 & 60 \\
20 & 260 & $?$ & $?$ & 201 & 1000 & 252 & $85^{+1}$ & $50^{-1}$ & 120 & $812^{+1}$ & $344^{+1}$ \\
- & & $?$ & $?$ & 436 & 48 & 587 & 90 & $166^{+1}$ & $261^{+1}$ & $(t)$ & $(t-2)$ \\
46 & 95 & 723 & 1000 & & & 58 & $(t)$ & & & & \\
14 & 50 & 760 & 1000 & 115 & 231 & 132 & 147 & $167^{+1}$ & 58 & $(t)$ & $(t-2)$ \\
15 & 115 & 680 & 1000 & 196 & 364 & 47 & 60 & $147^{+1}$ & 38 & $(t)$ & $(t-2)$ \\
- & 63 & 124 & 174 & 123 & 48 & 63 & 90 & $(t)$ & $(t-2)$ & 51 & 1000 \\
23 & 60 & 476 & 532 & 21 & 93 & 118 & 65 & $(t)$ & $(t-2)$ & 502 & 1000 \\
5 & 91 & 299 & 398 & 53 & 80 & 104 & 109 & 48 & 258 & 780 & 1000 \\
\hline
\end{tabular}

than that of the alkyl ions (at 1 a.m.u. lower) for the lower alkyl derivatives. These ions are included in Tables XI and XII under $\mathrm{m} / \mathrm{e} 57$ and 43 with the superscript ${ }^{+1}$. Prominent peaks in the spectra of $\mathrm{Zn}(\mathrm{DMDTC})_{2}$ and $\mathrm{Zn}(\mathrm{DEDTC})_{2}$ have earlier been aseribed to ions $a, c, d, e, f, g, h-1, h, i, l, r, s, u$ and $v^{7}, i^{12}$, but fragmentation pathways were indicated only for $a, d, e, f, g$ and $h^{12}$. The fragmentation pathways of the ligand in the mass spectra of sodium (N,N-dialkyldithiocarbamates) have also been reported ${ }^{9,12}$ and are in agreement with the fragmentation of $f(+1)$ in Fig. 10. The de- 


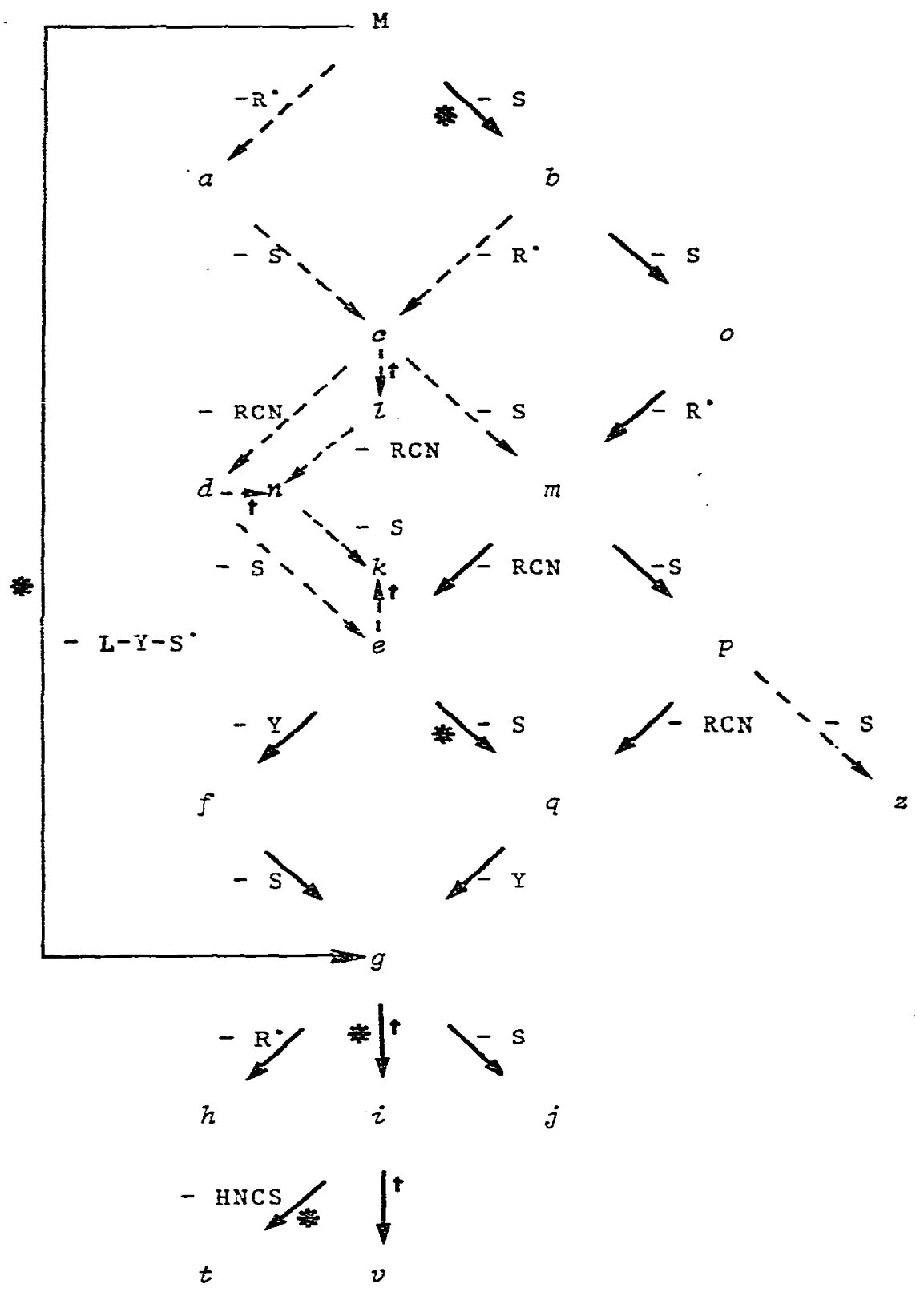

Fig. 11. Main fragmentation pathways of Ni(11) bis(N,N-dialkyldithiocarbamates). Main pathways are represented by full arrows and minor routes by dotted arrows. Confirmation by metastable transitions (a metastable was also observed for the decomposition of $e: e-\mathrm{H}_{2} \mathrm{~S} \rightarrow q-2$ ). For further explanation, see Fig. 10.

compositions $f+1 \rightarrow s, g \rightarrow u$ and $h \rightarrow h-1$ were proposed for the genesis of $s, u$ and $h$ (not included in Fig. 10).

It is interesting to compare the spectra of the nickel and zinc chelates with those of tri- and tetravalent metal derivatives ${ }^{8-10,16}$. The primary fragmentation process is 


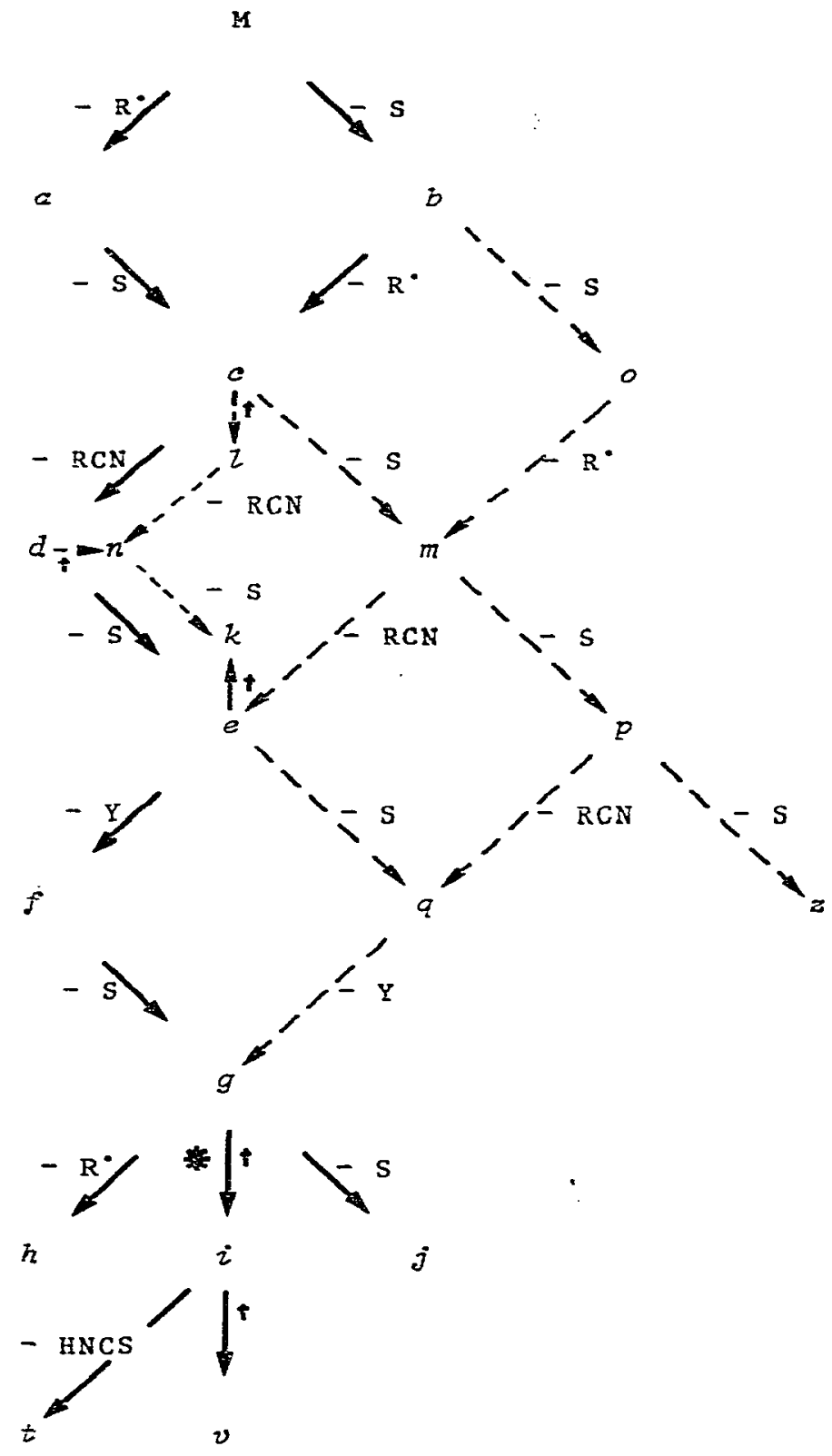

Fig. 12. Main fragmentation pathways of $\mathrm{Zn}(\mathrm{II})$ bis(N,N-dialkyldithiocarbamates). Main pathways are represented by full arrows and minor routes by dotted arrows. Confirmation by metastable transitions. For further explanation, see Fig. 10.

usually ligand loss, yielding abundant $\left[\mathrm{L}-\mathrm{Y}-\mathrm{Lj}^{+}\right.$ions. Important secondary fragmentations involve the loss of $S_{2}, C S_{2}$ and/or YS [often CS $t(s)$ is the base peak]. St is common, as are $\mathrm{Y}^{+}, \mathrm{Y}_{\mathrm{m}} \mathrm{S}_{n}{ }^{+}$and $\mathrm{YSC}^{+}$. None of these ions is found in the mass spectra of the nickel and zinc analogues with the exception of YS +2 , which is found in the spectra of the lower alkyldithiocarbamates of $\mathrm{Ni}$ - and $\mathrm{Zn}(\mathrm{DEDTC})_{2}$, as noted earlier. 


\section{ACKNOWLEDGEMENT}

This work was partially supported by a Scientific Exchange Agreement (S.E.A.) grant.

\section{REFERENCES}

1 J. Masaryk, J. Krupčik, J. Garaj and M. Košik, J. Chromatogr., 115 (1975) 256.

2 J. Krupčik, J. Garai, S. Holotik. D. Oktavec and M. Košik, J. Chromatogr., 112 (1975) 189.

3 T. J. Cardwell, D. J. Desarro and P. C. Uden, Anal. Chim. Acta., 85 (1976) 415.

4 M. Ahmad and A. Aziz, J. Chromatogr., 152 (1978) 542.

5 A. Tavlaridis and R. Neeb, Narurwissenschaften, 63 (1976) 146.

6 A. Tavlaridis and R. Neeb, Z. Anal. Chem., 282 (1976) 17.

7 J. F. Villa, D. A. Chatfield, M. M. Bursey and W. E. Hatfield, Inorg. Chim. Acta, 6 (1972) 332.

8 P. J. Hauser and A. F. Schreiner, Inorg. Chim. Acra, 9 (1974) 113.

9 K. W. Given, B. M. Mattson, G. L. Miessler and L. H. Pignolet, J. Inorg. Nucl. Chem., 39 (1977) 1309.

10 G. E. Manoussakis, E. D. Micromastoras and C. A. Tsipis, Z. Anorg. Allg. Chem., 403 (1974) 87.

11 C. A. Tsipis and G. E. Manoussakis, Inorg. Chim. Acta, 18 (1976) 35.

12 F. I. Onuska and M. E. Comba, J. Ass. Offic. Anal. Chem., 59 (1976) 622.

13 J. F. Villa, M. M. Bursey and W. E. Hatfield, Chem. Commun., (1971) 307.

14 I. W. Fraser, J. L. Garnett, I. K. Gregor and K. J. Jessop, Org. Mass Spectrom., 10 (1975) 69.

15 W. R. Benson and J. N. Damico, J. Ass. Offic. Anal. Chem., 51 (1968) 347.

16 G. K. Bratspies, J. F. Smith, J. D. Hill and R. J. Magee, Thermochim. Acta, 19 (1977) 335, 349 and 361.

17 J. Krupčik, M. Kristin, M. Valachovičová and S. Janiga, J. Chromatogr., 126 (1976) 147.

18 J. J. Franken, G. A. F. M. Rutten and J. A. Rijks, J. Chromatogr., 126 (1976) 117.

19 J. Bouche and M. Verzele, J. Gas Chromatogr., 6 (1968) 501.

20 D. M. Ottenstein, Advan. Chromatogr., 3 (1966) 137.

2l E. Brandšteterová, unpublished results.

22 E. Kovảts, Advan. Chromatogr., 1 (i965) 229.

23 J. Krupčik, K. Tesařik, O. J. Liška, J. Němec and Y. P. Duchesne, Chronatographia, 5 (1972) 252.

24 G. A. F. M. Rutten and J. A. Luyten, J. Chromatogr., 74 (1972) 177.

25 L. S. Ettre, Open Tubular Columns in Gas Chromatography, Plenum Press, New York, 1965. 